\title{
PENGARUH PENGURANGAN TONGKOL TIDAK BERKEMBANG DAN PEMBERIAN DOSIS NITROGEN TERHADAP HASIL TANAMAN JAGUNG (Zea mays L.) VARIETAS LOKAL SERAYA
}

\author{
Kristina Erniyani*), A.A. Made Sudira Djelantik ${ }^{2}$ ) dan Sang Made Sarwadana ${ }^{2}$ ) \\ 1) Jurusan Agroekoteknologi Fakultas Pertanian Universitas Flores \\ 2) Jurusan Budidaya Fakultas Pertanian Universitas Udayana \\ erni03_uniflor@yahoo.co.id
}

\begin{abstract}
The Effects of Decreasing Ungrowth Stem Earn of Corn and Fertilized Corn Yield Seraya Local Variety with Nitrogen Rates

THIS research conducted to know the effect of decreasing ungrowth stem earn of corn and fertilized corn yield seraya local variety with nitrogen rates and interaction. The experimental factor is decrease unproductive stem earn consist left behind 1 stem earn (Tl), decrease by left behind 2 stem earn (T2) and without decrease (T3). The second factor is nitrogen dosage by 0,115 and $172,5 \mathrm{~kg} \mathrm{~N} / \mathrm{ha}$.

The result of research indicated a real and extremely real interaction between both of treatment factor $(\mathrm{T} \times \mathrm{N}$ ) only happen on amount of variable seed per line and amount of seed per crop. Treatment without decreasing ungrowth stem earn (T3) caused highly weight dry seed oven per hectar is 2,67 ton and lowest on decreasing ungrowth stem earn treatment to left behind 1 stem earn ( $\mathrm{Tl}$ ) is 1,81 ton. Nitrogen treatment $115 \mathrm{~kg} / \mathrm{ha}(\mathrm{N} 2)$ caused highly weight dry seed oven 2,97 ton/ha and lowest 1,56 ton by $0 \mathrm{~kg} / \mathrm{ha}$ nitrogen dosage.
\end{abstract}

Keyword : nitrogen fertilize, Zea mays, stem earn.

\section{PENDAHULUAN}

Hasil penelitian Sumerta (1990) menunjukkan jagung varietas lokal Seraya mempunyai umur panen yang relatif lebih pendek (deskripsi pada Tabel 1). Data ini didukung oieh penelitian Sugiarta (1994) yang mendapatkan umur panen jagung varietas lokal Seraya adalah 90,83 hari setelah tanam (hst) dan Herniati (1999) mendapatkan umur panen jagung varietas lokal Seraya adalah 91,33 hst atau lebih cepat 10,7 dari vaietas Bisi-2. Disamping itu varietas lokal Cicih Tombong (lokal Seraya), memungkinkan dikembangkan ke arah pembentukan varietas unggul baru bersari bebas, atau varietas sintesis dan tahan pada lahan kering (Sudarka, 1997).

Hasil penelitian Herniati (1999) menunjukkan bahwa pada jarak tanam $75 \mathrm{~cm} \mathrm{x}$ $20 \mathrm{~cm}$ jagung varietas lokal Seraya mampu membentuk tongkol sebanyak 3,130 buah sedangkan varietas Bisi-2 mampu membentuk 1,750 buah, tetapi hasil biji kering oven per hektar (ton) lebih rendah pada varietas lokal Seraya (3,905 ton) dibandingkan varietas Bisi-2 (10,06 ton), selanjutnya dijelaskan dari 3,130 buah tongkol terbentuk pada varietas lokal Seraya hanya 1,000 buah tongkol yang produktif, sedangkan 1,517 buah termasuk dalam tongkol tidak berkembang dan 0,613 buah termasuk tongkol tidak produktif.

Tinggi rendannya hasil biji yang diperoleh tergantung dari kualitas "source" (sumber asimilat) dan "sink" (pengguna, penampung asimilat), baik secara parsial maupun bersamasama, di samping asimilat ke biji (Gifford, 1974) dalam (Sumerta, 1990). Pengurangan tongkol s yang tidak berkembang dan pemberian pupuk nitrogen dapat menjadi salah satu upaya untuk meningkatkan hasil biji jagung varietas local Seraya.Pengurangan tongkol yang dilakukan adalah diharapkan pada saat pengisian biji kompetisi kompetisi "sink" terhadap asimilasi dapat dikurangi sehingga pengisian biji pada tongkol-tongkol yang tertingga lebih optimal. 
Tabel 1.Deskripsi Jagung Varietas Lokal Seraya

\begin{tabular}{ll}
\multicolumn{1}{c}{ Deskripsi } & \multicolumn{1}{c}{ Keterangan } \\
\hline Asa I & Seraya, Karangasem (Bali) \\
Golongan & Bersari bebas \\
Umur & $50 \%$ "silking" \pm 56 hst. Panen $85-97$ hst \\
Batang & Tinggi, garis tengah batangnya besar \\
Daun & Panjang dan kurus, jumlahnya \pm 13 helai \\
Tongkol & Kecil, pendek \pm 8-12 cm dan jumlahnya lebih dan satu \\
Warna biji & Putih \\
Warna daun & Hijau \\
Warna batang & Hijau \\
Klobot & Menutup tongkol dengan baik \\
Bar is biji & Cukup lurus dan rapi \\
Kedudukan tongkol & Mulai 3 daun dari pangkal batang sampai 5 daun ujung batang \\
Jumlah baris per tongkol & 8 sampai 9 baris \\
Bobot 1000 biji & \pm 196 gram \\
Potensi hasil & Rata-rata 42,77 ku/ha \\
\hline
\end{tabular}

Sumber : Sumerta (1990)

Nitrogen yang tersedia bagi tanaman dapat mempengaruhi pembentukan protein, unsure $\mathrm{N}$ juga merupakan bagian integran dari klorofil dan membentuk warna hijau pada tanaman. Bila tanaman kekurangan $\mathrm{N}$, pembentukan karbohidrat akan tertunda pada fase vegetatif, sebaliknya jika suplai $\mathrm{N}$ cukup, pertumbuhan tanaman akan berjalan dengan baik selanjutnya karbohidrat akan terbentuk yang kemudian akan ditransformasikan menjadi protein dan apabila kelebihan $\mathrm{N}$ mengakibatkan tanaman bersifat sukulen

(Koswara, 1982). Gardner dan Pearce (1985) mengatakan nitrogen merupakan bahan penting penyusun asam amino, amida, nukleutida, nukleuprotein dan esensial untuk pembetukan sel, pembesaran sel yang akan mendukung pertumbuhan tanaman. Kekurangan nitrogen membatasi pembesaran sel dan pembelahan sel. Gejalanya meliputi pertumbuhan tanamannya kerdil dan kuning terutama pada bagian-bagian tanaman yang lebih tua.

Penelitian ini bertujuan untuk mengetahui pengaruh pengurangan tongkol tidak berkembang dan pemberian dosis nitrogen serta interaksinya terhadap hasil jagung (Zea mays) varietas local Seraya.

\section{BAHAN DAN METODE}

\footnotetext{
Penelitian ini dilakukan di Kebun percobaan Fakultas Pertanian Universitas Udayana - Denpasar Bali.

Percobaan lapangan dengan Rancangan Acak Kelompok yang disusun secara factorial. Factor pertama adalah pengurangan tongkol tidak berkembang ( $\mathrm{T})$ yang terdiri atas $\mathrm{Tl}$ (pengurangan tongkol tidak berkembang hingga
}

meninggalkan 1 tongkol). T2 (pengurangan tongkol tidak berkembang hingga meninggaikan 2 tongkol), T3 (Tanpa pengurangan tongkol). Faktor kedua adalah dosis pupuk nitrogen yang terdiri atas NO (0 kg N/ha atau $0 \mathrm{~kg}$ urea/ha), Ni $(57,5 \mathrm{~kg}$ $\mathrm{N} / \mathrm{ha}$ atau $125 \mathrm{~kg}$ urea/ha), N2 (115 kg N/ha atau $250 \mathrm{~kg}$ urea/ha), N3 (172,5 kg N/ha atau $375 \mathrm{~kg}$ urea/ha). Masing-masing perlakuan diulang sebanyak 3 kali, sehingga terdapat 36 petak percobaan.

Lahan yang dipakai adalah lahan dengan kadar $\mathrm{N}$-total sangat rendah $(0,08 \%)$, C-organik sangat rendah $(0,84 \%)$, P-tersedia sangat tinggi (76?51 \%) dan K-tersedia rendah $(95,14 \%)$, tekstur lempung berliat. Petak percobaan dibuat dengan ukuran $3 \mathrm{~m} \times 1,5 \mathrm{~m}$ dengan jarak antar petak dalam satu ulangan $0,5 \mathrm{~m}$ dan jarak antar ulangan $1 \mathrm{~m}$, tinggi petak $30 \mathrm{~cm}$. Jarak tanam 75 $\mathrm{cm} \times 25 \mathrm{~cm}$, tiap lubang terdiri dari satu tanaman.

Bahan yang digunakan adalah jagung varietas lokal Seraya yang ditanam dengan kedalaman $3-5 \mathrm{~cm}$ dan tiap lubangnya diisi 2-3 biji jagung. Untuk mencegah penyakit bulai sebelum ditanam benih dicampiir dengan ridomil 35 SD. Pestisida nabati berupa air rebusan daun sirih disemprotkan ketika tanaman terserang kutu. Pupuk urea sesuai perlakuan yang diberikan dalam 2 tahap yaitu sepertiga bagian diberikan pada saat tanam dan dim per tiga diberikan pada umur 30 hst. Pupuk $\mathrm{KCl}$ diberikan. Penyiraman mulai dilakukan sejak penanaman dan selanjutnya disesuaikan dengan keadaan. Penyulaman dilakukan pada 7 hst untuk menggantikan tanaman yang rusak atau mati dengan tanaman yang umurnya sama, dan masing-masing lubang hanya dibiarkan satu tanaman. Penyiangan pertama dilakukan 15 hst selanjutnya disesuaikan dengan keadaan di lapangan. Pengurangan tongkol sebagai perlakuan dilaksanakan pada umur $74 \mathrm{hst}$ 
atau 8 hari seteiah fase 5. Koswara (1982) menyatakan penyebaran tepung sari yang umumnya terjadi berkisar 7 hari, sedangkan.daya tampung rambut berkisar 7-10 hari.

Menurut Hanway (1966, dalam Ginting, 1988) keadaan ini telah mencapai fase 5 yang terjadi 66 hst dan ditandai dengan rambutrambut telah keluar dan tepung sari (pollen) mulai jatuh, tongkol dan klobot mendekati perkembangan sempurna. Panen dilakukan apabila $90 \%$ tanaman jagung dalam petak telah mencapai masak fisiologi yang ditandai dengan sebagian besar daun dan klobotnya telah menguning, bila bijinya ditekan memakai kuku tidak menimbulkan bekas dan telah terbentuk lapisan hitam pada pangkal biji yang berhubungan dengan jenggel.

Variabel pengamatan antara lain tinggi tanaman, indeks luas daun (ILD), jumlah daun, jumiah baris per tongkol, jumlah biji per tongkol, jumlah biji per baris, jumlah biji per tanaman, panjang tongkol, diameter tongkol yang berisi biji, berat 100 biji kering oven, berat biji kering panen per tanaman, berat biji kering oven per tanaman, berat biji kering panen per hektar, berat biji kering oven per hektar, kadar air biji kering panen, berat brangkasan kering oven per tanaman dan indeks panen.

\section{HASIL DAN PEMBAHASAN}

Pengurangan tongkol tidak berkembang memberikan berat biji kering oven per hektar dan berat biji kering oven per hektar dan berat biji kering oven per tanaman tertinggi pada perlakuan tanpa pengurangan tongkol (T3) sebesar 2,67 ton/ha dan 65,26 gram/tanaman. Berat biji kering oven tanaman didukung oleh berat biji kering panen per tanaman $\left(\mathrm{r}=0,776^{* *}\right)$ dan jumlah biji per tanaman $(\mathrm{r}=0,707 * *)$.

Tabel 2. Rata-rata panjang tongkol $(\mathrm{cm})$, diameter tongkol $(\mathrm{cm})$, berat 100 biji kering oven $(\mathrm{g})$ dan berat biji kering panen per tanaman $(\mathrm{g})$ pada periakuaii pengurangan tongkol tidak berkembang dan dosis nitrogen

\begin{tabular}{lcccc}
\multicolumn{1}{c}{ Perlakuan } & $\begin{array}{c}\text { Panjang } \\
\text { tongkol }(\mathrm{cm})\end{array}$ & $\begin{array}{c}\text { Diameter } \\
\text { tongkol }(\mathrm{cm})\end{array}$ & $\begin{array}{c}\text { Berat } 100 \mathrm{biji} \\
\text { KO }(\mathrm{gram})\end{array}$ & $\begin{array}{c}\text { Berat biji KP per } \\
\text { tanaman }(\text { gram })\end{array}$ \\
\hline $\begin{array}{l}\text { Pengurangan tongkol tidak } \\
\text { berkembang }\end{array}$ & & & & \\
T1 = meninggalkan I tongkol & $10,69 \mathrm{a}$ & $2,98 \mathrm{~b}$ & $18,35 \mathrm{a}$ & $51,16 \mathrm{c}$ \\
T2 = meninggalkan 2 tongkol & $10,24 \mathrm{ab}$ & $3,16 \mathrm{a}$ & $19,20 \mathrm{a}$ & $61,58 \mathrm{~b}$ \\
T3 = tanpa pengurangan & $9,77 \mathrm{~b}$ & $3,02 \mathrm{ab}$ & $18,08 \mathrm{a}$ & $76,22 \mathrm{a}$ \\
\hline BNT 5\% & 0,59 & 0,14 & 1,35 & 10,00 \\
\hline Dosis nitrogen & & & & \\
NO=0 kg N/ha & $9,61 \mathrm{~b}$ & $2,97 \mathrm{a}$ & $17,54 \mathrm{~b}$ & $51,68 \mathrm{~b}$ \\
$\mathrm{~N} 1=57,5 \mathrm{~kg} \mathrm{~N} / \mathrm{ha}$ & $10,03 \mathrm{~b}$ & $3,09 \mathrm{a}$ & $17,95 \mathrm{~b}$ & $65,33 \mathrm{a}$ \\
$\mathrm{N} 2=115 \mathrm{~kg} \mathrm{~N} / \mathrm{ha}$ & $10,95 \mathrm{a}$ & $3,13 \mathrm{a}$ & $19,60 \mathrm{a}$ & $68,70 \mathrm{a}$ \\
$\mathrm{N} 3=172,5 \mathrm{~kg} \mathrm{~N} / \mathrm{ha}$ & $1034 \mathrm{a}$ & $3,02 \mathrm{a}$ & $19,08 \mathrm{a}$ & $66,22 \mathrm{a}$ \\
\hline $\mathrm{BNT} 5 \%$ & 0,68 & 0,16 & 1,56 & 11,54 \\
\hline
\end{tabular}

Keterangan :

Nilai rata-rata yang diikuti huruf yang sama pada perfakuan dan kolom yang sama menunjukkan perbedaan yang tidak nyata pada uji BNT taraf 5\%

Tabel 2 menunjukkan berat 100 biji kering oven tertinggi pada T2 yaitu 19,20 gram atau terjadi peningkatan sebesar $6,20 \%$ dibandingkan dengan T3 yaitu 18,08 gram. Peningkatan berat 100 biji kering oven karena perlakuan pengurangan tongkol didukung oleh meningkatnya diameter tongkol dimana tertinggi diperoleh pada T2 $(3,16 \mathrm{~cm})$. Meningkatnya diameter diikuti oleh meningkatnya jumlah biji per tongkol. Hal ini diduga bahwa meningkatnya diameter tongkol akibat pengurangan tongkol tidak berkembang akan menyebabkan biji lebih bernas sehingga berat 100 biji kering oven juga meningkat.
Hasil penelitian menunjukkan bahwa dengan pengurangan tongkol tidak berkembang menurunkan hasil per tanaman. Penurunan berat biji kering oven pada $\mathrm{Tl}$ dan $\mathrm{T} 2$ sebesar 22,14\% dan 33,80\% dibandingkan dengan T3 diduga disebabkan oieh jumlah permintaan akan asimilat berkurang, yang mana pada T3 terdapat tongkoltongkol yang tidak menghasilkan biji. Hal ini didukung oleh pendapat Neales dan Incoll (1968) dalam Fischer dan Palmer (1984) yang mengatakan bahwa laju produksi bahan kering akan dipengamhi oleh permintaan asimilasi selama pengisian biji. Gifford dan Evans (1981) dalam Gardner dan Pearce (1985) mengatakan agar fotosintesis daun dapat. tercapai, daerah 
pemanfaatan hams dapat memanfaatkan seluruh hasil hasil asimilasi yang diprodLiksi. Goldworthy dan Tailor, 1970 dan Moss (1962) dalain Goldworthy (1984) menunjukkan bahwa bila biji dihilangkan atau dibuat kecil, bahan kering yang seharusnya ke biji lertimbun dalam batang jagung. Penurunan berat biji kering oven per tanaman juga disebabkan oleh jumlah biji yang dipanen semakin berkurang dengan semakin meningkatnya pengurangan tongkol. Meski berat 100 biji kering oven meningkat tetapi karena jumlah biji per tanaman semakin sedikit maka hal ini tidak mampu mengimbangi berat biji yang lebih rendah dengan jumlah yang lebih banyak. Hal ini berarti bahwa pada biji yang berukuran kecil diikuti oleh berat biji yang semakin rendah, tetapi dalam jumlah yang lebih banyak pada T3 tetap mempunyai berat kering oven per tanaman lebih tinggi dibandingkan dengan berat biji yag berukuran besar dan dengan berat yang lebih tinggi pada $\mathrm{T} 2$. Demikian pula dengan berat kering oven per hektar.

Hasil penelitian menunjukan pemberian nitrogen $115 \mathrm{~kg} / \mathrm{ha}(\mathrm{N} 2)$ dapat memberikan berat biji kering panen per hektar dan berat biji kering oven per hektar tertinggi yaitu sebesar 4,29 ton/ha dan 2,79 ton/ha atau meningkat $106,25 \%$ dan $90,35 \%$ dibandingkan dengan perlakuan $0 \mathrm{~kg} \mathrm{~N} / \mathrm{ha}$ (NO). Berat biji kering oven per hektar didukung oleh berat biji kering oven per tanaman $(\mathrm{r}=0,612 * *)$; berat 100 biji kering oven $\left(\mathrm{r}=0,422^{*} *\right)$; diameter tongkol $(\mathrm{r}=$ $0,452 * *)$; panjang tongkol $\left(\mathrm{r}=0,333^{*}\right)$; jumlah biji per tanaman $\left(\mathrm{r}=0,775^{* *}\right)$.

Berat biji kering panen per tanaman dan berat biji kering oven per tanaman meningkat sejalan dengan meningkatnya dosis nitrogen kecuali pada dosis 172,5 kh/ha (N3). Penambahan dosis nitrogen mengakibatkan panjang dan diameter tongkol tertinggi pada N2 yaitu $10,95 \mathrm{~cm}$ dan $3,13 \mathrm{~cm}$. demikian pula jumlah biji per tongkol tertinggi pada N2 yaitu 210,12 biji. Wolfe dan Kips (1959) dalain Mimbar (1990) menyatakan bahwa dengan meningkatnya dosis nitrogen sampai batas tertentu, diameter tongkol makin besar dan makin penuh diisi oleh biji sehingga berat biji per tanaman meningkat. Bertambahnya jumlah biji per tongkol diduga ada hubungan dengan pembentukan protein akibat bertambahnya unsure nitrogen. Nitrogen merupakan unsure utama penyusun protein yang digunakan untuk membentuk protoplasma dan cadangan makanan (Harjadi, 1-979) yang selanjutnya mempengaruhi jumlah biji yag terbentuk dan memperbesar ukuran biji (Koswara, 1982).
Berat 100 biji kering oven meningkat dengan meningkatnya dosis nitrogen kecuali pada dosis $172,5 \mathrm{kgN} / \mathrm{ha}$. Semakin besar berat 100 biji kering oven menunjukan makin besar biji. Hal ini dapat dilihat bahwa meningkatnya dosis nitrogen memberikan panjang dan diameter tongkol terbesar pada N2 yaitu $10,95 \mathrm{~cm}$ dan $3,13 \mathrm{~cm}$. meningkatnya diameter tongkol tidak menyebabkan jumlah baris meningkat. tetapi meningkatnya diameter tongkol disebabkan oleh biji-biji yang terbentuk lebih bernas.

Hasil yang dicapai oleh suatu tanaman juga didukung oleh tinggi tanaman, indeks luas daun dan jumlah daun. Hasil penelitian ini menunjukan bahwa berat biji kering oven per tanaman ditunjang oleh tinggi tanaman ( $\left.\mathrm{r}-0,445^{* *}\right)$; indeks luas daun $\left(\mathrm{r}=0,369^{*}\right)$ dan jumlah daun ( $\mathrm{r}$ $=0,432 * *)$.

Pemberian dosis nitrogen dapat meningkatkan pertumbuhan vegetatif. Hal ini terlihat bawa tinggi tanaman dan jumlah daun tertinggi pada N3 yang masing-masing sebesar $220,13 \mathrm{~cm}$ dan 12,00 helai. Meningkatnya tinggi tanaman dan jumlah daun menyebabkan berat brangkasan kering oven meningkat. Hal ini dibuktikan adanya hubungan antara tinggi tanaman dan jumlah daun terhadap berat brangkasan kering oven $\left(r=0,583^{* *}\right)$ dan $(r=$ $\left.0,690^{* *}\right)$. Unsure nitrogen yang bertungsi untuk pembentukan asimilat dan karbohidrat selama fase vegetatif, karbohidrat yang terbentuk digunakan untuk pembentukan sel-sel baru, perpanjangan sel dan penebalan jaringan (Harjadi, 1979). Laju penebalan dan pemanjangan sel serta pembentukan jaringan berjalan cepat sesuai dengan meningkatnya persediaan karbohidrat, sehingga pertumbuhan tanaman juga berjalan cepat. Fase vegetatif ini berlangsung sampai bunga jantan keluar dan tanaman telah mencapai tinggi maksimum, selanjutnya relative konstan karena tanaman telah memasuki fase generatif. Jika pembentukan tongkol dan biji sudah berlangsung, maka karbohidrat yang terbentuk disimpan dalam biji.

Pada jumlah biji per baris terdapat interaksi yang nyata akibat perlakuan pengurangan tongkol tidak berkembang dan pemberian dosis nitrogen. Rata-rata jumlah biji per baris tertinggi pada $\mathrm{Tl}$ terhadap N2 yang berbeda tidak nyata terhadap T2 dan T3.Pada jumlah biji per tanaman terdapat interaksi yang nyata akibat perlakuan pengurangan tongkol tidak berkembang dan pemberian dosis nitrogen. Jumlah biji per tanaman tertinggi pada T3 terhadap N1 yang berbeda nyata terhadap $\mathrm{T} 1$ dan $\mathrm{T} 2$

Hasil penelitian menunjukkan bahwa pemberian nitrogen menurunkan indeks panen. Pada NO, pertumbuhan tanaman (tinggi tanaman 
dan jumlah daun) paling rendah mengakibatkan berat biji per tanaman rendah yaitu 44,07 gram. Pada N, berat biji kering oven per tanaman paling tinggi yaitu 57,93 gram dengan pertumbuhan tanaman lebih tinggi dari NO. meningkatnya berat biji kering oven per tanaman pada N2 tidak sebanding dengan bertambahnya nitrogen, artinya nitrogen yang diberikan pada perlakuan N2 mampu meningkatkan berat biji kering oven per tanaman hanya sebesar $31,45 \%$, sedangkan berat berangkasan kering ove per tanaman meningkat sebesar $62,94 \%$ dibandingkan dengan NO. Keadaan ini menyebabkan indeks panen pada NO lebih besar dibandingkan dengan N1,N2danN3.

\section{SIMPULAN}

Berdasarkan hasil penelitian dapat disimpulkan bahwa interaksi perlakuan pengurangan tongkol tidak berkembang dan pemberian dosis nitrogen memberi pengaruh yang tidak nyata terhadap berat biji kering oven per hektar. Pengurangan tongko! tidak berkembang tidak dapa meningkatkan berat biji kering oven per hektar atau tidak dapat meningkatkan hasil penen, sedangkan pemberian pupuk nitrogen menyebabkan berat biji kering oven per hektar tertinggi pada dosis $115 \mathrm{~kg} \mathrm{~N} /$ ha yaitu 2,97 ton/ha atau meningkat sebesar $90,35 \%$ dibandingkan dengan perlakuan $0 \mathrm{~kg} \mathrm{~N} / \mathrm{ha}$.

\section{UCAPAN TERIMA KASIH}

Ucapan terima kasih disampaikan kepada Tuhan yang telah memberikan waktu dan kuasaNya, untuk Keluarga Mama Paulina, aim. ayahanda Gabriel, Martha, Marsei, lien, Gina dan Emi atas dukungan doa dan terima kasih juga disampaikan kepada semua teman-taman atas segala bantuannya dalam pelaksanaan penelitian di lapangan.

\section{DAFTAR PUSTAKA}

Fischer, K.S dan A.F.E Palmer. 1984. Jagung Tropik: Dalarn P.R Goldworthy and N.M Fisher. Fisiologi Tanaman Budidaya Tropik. Terjemahan oleh Tohari. Gajah
Mada University Press. Yogyakarta. Hal 281-328

Gardner, F.P and R.B. Pearce. 1985. Fisiologi Tanaman Budidaya. Terjemahan oleh Herawati Susilo. Penerbit Universitas Indonesia. Jakarta. 428 hal

Goldworthy, P.R. 1984. Pertumbuhan dan Perkembangan Tanaman Dalam P.R Goldworthy and N.M Fisher. Fisioiogi Tanaman Budidaya Tropik. Terjemahan oleh Tohari. Gajah Mada University Press. Yogyakarta. Hal 214 - 280

Hanway (1966, dalam Ginting, O. 1988. Pengaruh Pemangkasan Dini terhadap Pertumbuhan, Hasil dan Komponen Hasil Beberapa Varietas Tanaman Jagung (Zea mays L.). Tesis Fakultas Pasca Sarj'ana. ITB. 90 hal.

Harjadi, S.S. 1979. Pengantar Agronomi. PT Gramedia.Jakarta. 197 hal

Herniati, N.L. 1999. Potensi Jumlah Tongkol dan Hasil pada beberapa Varietas Jagung (Zea mays L.) dengan Variasi Jarak Tanam. Skripsi Jurusan Budidaya Pertanian. Fakultas Pertanian. Universitas Udayana. Denpasar (tidak dipublikasikan).

Koswara, J. 1982. Diktat Kuliah Ilmu Tanaman Setahun: Jagung. Depertemen Agronomi. Fakultas Pertanian IPB. 150 hal

Mimbar, S.M. 1990. Pola Pertumbuhan dan Hasil Penen Jagung Kretek

karena Pengaruh Pupuk N. J. Agrovita (ed. Agustus - Desember 1990) 13 (3) 82 89.

Sudarka, W. 1997. Evaluasi Keragaman Tanaman jagung Varietas Lokal Bali Cicih Tombong pada Sistem Tanam Monokultur dan Tumpang Sari. Tesis. Program Studi Agronomi. Jurusan Umu-Umu Pertanian. Universitas Gajah Mada.

Sugiarta, A. A. 1994. Tanggapan beberapa Varietas Jagung Lokal Bali Terhadap Pemangkasan Bunga Jantan. Skripsi Jurusan Budidaya Pertanian. Fakultas Pertanian. Universitas Udayana. Denpasar (tidak dipublikasikan).

Sumerta, M. G. 1990. Seleksi Plasma Nutfa Jagung Lokal Bali. Skripsi Jurusan Budidaya Pertanian. Fakultas Pertanian. Universitas Udayana. Denpasar (tidak dipublikasikan). 